\title{
Türkiye'de Tek Partili Dönemde Ulusal Kalkınma Hedefi ve Köy Enstitüleri
}

\author{
National Development Goal and Village Institutes in The Single Party Perlod in Turkey
}

\section{Çiğdem ERDEM}

Doç. Dr., Ankara Hacı Bayram Veli Üniversitesi,

IIBF, Siyaset Bilimi ve Kamu Yönetimi Bölümü,

cigdem.erdem@hbv.edu.tr

https://orcid.org/0000-0002-4030-8750
Makale Başvuru Tarihi: 25.06.2021

Makale Kabul Tarihi: 07.08.2021

Makale Türü: Araştırma Makalesi

\section{Anahtar \\ Kelimeler:}

Tek Parti Dönemi,

Kalkınma,

Köy Enstitüleri,

Keywords:

Single Party Period,

Development,

Village Institutes,

\section{ÖZET}

Bu çalışma, tek parti yönetimin köy enstitülerinden beklentileri ve enstitülerin faaliyetleri kapsamında, enstitü-kalkınma ilișkisini ortaya koymayı amaçlamaktadır. Burada söz konusu olan kalkınma, yerel/bölgesel ya da köye içkin değil bütün bir ülke kapsamında; ulusal kalkınmadır. Bu sebepten çalışmada kalkınma kavramı, bütünsel bir çerçevede ele alınmıştır. Burada bütünsellikle kastedilen hem mekânsal ve sosyolojik anlamda, kur/köy/bölge ölçeğini aşan ulus ölçeğidir hem de ekonomik ve toplumsal anlamda birbirini tamamlayan kalkınma anlayışıdır. Nitekim literatüre özellikle de II. Dünya Savaşı sonrası dönemde ilk olarak ekonomik büyüme ile ilintili bir kavram olarak giren kalkınma kavramı, 1970'lerden sonra ekonomi ile birlikte, toplumsal, siyasal, kültürel ve insani alanları da kapsayacak bir biçimde, tüm bu alanların birbirini desteklediği bütünsel bir çerçevede ele alınmaya başlanmıştır. Çalışmanın üç temel savı vardır bunlardan birincisi; enstitülerin tek parti yönetimi açısından köy ögretmeni yetiştirmekten daha derin anlamlar taşıdiğ ikincisi; buradaki derin anlam olarak ifade ettiğimiz kavramın kalkınma kavramına denk düştüğü üçüncüsü; bu kalkınmanın ölçeğinin bütün bir ulus olduğudur. Çalışmanın kapsamı enstitülerin kurulduğu 1940 yılı ile çok partili hayata geçişin geçekleştiği 1945 yılları arasıdır. Çünkü çok partili siyasal hayata geçişin ardından siyasette ortaya çıkan yeni dengelerle birlikte, tek parti yönetiminin enstitülerden beklentileri ve buna paralel olarak da enstitülerin kalkınma hedefi bir dönüşüm geçirmiştir. Çalışma nitel araştırma yöntemine göre; "kalkınma kavramı", "köy enstitüleri pratiği”" ve "ulusal kalkınmanın aracı olarak köy enstitüleri” konulu üc bölüm halinde kurgulanmıştır.

\begin{abstract}
This study aims to reveal the institute-development relationship within the scope of the expectations of the single-party administration from the village institutes and the activities of the institutes. The development in question here is not local/regional or immanent to the village, but is national development within a whole country. For this reason, the concept of development is discussed in a holistic framework in this study. The meaning of holism here is the national scale that exceeds the rural/village/regional scale in spatial and sociological sense, and the understanding of development that complements each other economically and socially. As a matter of fact, the concept of development, which first entered the literature as a concept related to economic growth, especially in the post-World War II period, has begun to be considered in a holistic framework, in which all these fields support each other, including the economic, social, political, cultural and humanitarian fields after the 1970s. The study has three main arguments, the first of which is that institutes have deeper meanings than raising village teachers in terms of single-party management; second of them is that the concept we refer to as the deep meaning here corresponds to the concept of development; third is that the scale of this development is that of an entire nation. The scope of the study is between 1940 when the institutes were founded and 1945 when the transition to multi-party life took place. Because, with the new balances that emerged in politics after the transition to multi-party political life, the expectations of the single-party administration from the institutes and, in parallel, the development goal of the institutes have undergone a transformation. According to the qualitative research method of the study; it the study has been structured in three sections on "development concept", "village institutes practice" and "village institutes as a instrument of national development".
\end{abstract}




\section{GIRISS}

$\mathrm{Bu}$ çalışma, tek partili dönemde köy enstitüleri ile ulusal kalkınma hedefi arasında kurulan ilişkiyi ortaya koymaktadır. Başka bir ifadeyle çalışmanın amacının, tek parti yönetiminin köy enstitülerinden beklentilerinin neler olduğunu belirlemek olduğu da söylenebilir. Çünkü bu beklentiler, çalışma içerisinde de inceleneceği gibi "ulusal kalkınma" kavramına denk düşmektedir.

Kalkınma kavramı, Batı kaynakı bir kavram olarak ekonomi literatüründe, II. Dünya Savaşından sonra en genel anlamıyla ekonomik büyüme anlamında kullanılmaya başlanmış ancak 1970'lerden sonra kavram bir genişleme içerisine girerek daha bütünsel bir yaklaşımla, ekonomi dâhil toplum, insan, siyaset sarmalında ele alınmaya başlanmıştır.

Köy enstitüleri ise fiiliyatta kökleri 30'lu yıllara kadar gitse de resmi olarak 1940 yılında; yani bu çalışmanın incelediği dönem itibariyle kalkınma kavramının, henüz sosyal bilimler disiplininde kullanılmaya başlanmadığı bir dönemde kurulmuşlardır. Buna karşlık Türkiye'de köy enstitüleri ile ilgili literatürde, köy enstitülerini ekonomik kalkınma, toplum kalkınması, kültürel kalkınma ve köy ya da kır kalkınması ile ilişkilendiren onlarca makale, kitap ve tez bulunmaktadır. Şu durumda kronoloji bize bu ikili arasında anakronik bir ilişki kurulduğunu söylemektedir.

Çalışmada konuyla ilgilenen diğer araştırmacıların takip ettiği yoldan gidişmiştir. Ancak olaya daha da geniş bir perspektiften yaklaşılmıştır. Bu çalışmada enstitüler ile kalkınma kavramı arasında kurulmaya çalışılan ilişki yerel, bölgesel, kır ya da köy temelinde değerlendirilmemiş; kalkınma sadece toplumsal veya ekonomik boyutla ele alınmamış, topyekûn bir ulusal kalkınma kavramı ile açıklanmaya çalışılmıştır. Bunun sebebi tek parti yönetiminin, köy enstitüleri ile ekonomik, toplumsal, kültürel ve siyasal alanların her birine uzanma ve bu alanların her birini dönüştürme isteğinden ve bir de mevcut şartlar altında köyün ve köylünün mekânsal ve sosyolojik olarak kapsamının tüm bir ülke sathına denk düşebilecek bir genişlik ve yoğunlukta olmasından kaynaklanmaktadır. Dolayısıyla bu çalışmada kalkınmanın "ulusal”lığı, enstitülerin köy/kır/bölge ile değil bütün bir ülke ile ilişkilendirilmesini ifade etmektedir. Kalkınma-enstitü ilişkisine dair bu geniş perspektif dışında, neden henüz kalkınma kavramının kullanılmadığı dönemde kurulmuş olan enstitülerin, kalkınma kavramı ile açıklanabileceği savına gelince; aşağıda da ayrıntısı ile inceleneceği üzere, enstitülerden tek parti yönetiminin beklentileri ve bu beklentilere uygun olarak enstitülerin faaliyetleri, tam da kalkınma kavramının 70 sonrasında kazandığı anlama denk düşmektedir.

Verilen bilgilerden harektle bu çalışma, ilk olarak tek parti yönetimi açısından Köy Enstitülerinin, köylere öğretmen yetiştirecek bir eğitim kurumu olmanın çok ötesinde bir anlam ifade ettiğini, ikinci olarak bu anlamın kalkınma kavramı ile ifade edilebileceğini ve üçüncü olarak da söz konusu kalkınmanın köyden ibaret olmayıp, bütün bir ulusa yöneldiğini savunmaktadır. Bu savların geçerliliğini ortaya koyabilmek için çalışma üç ana bölüm etrafında kurgulanmıştır. İlk olarak kalkınma kavramı, kavramın tarihsel ve buna eşlik eden semantik serüveni incelenecek ve kalkınma kavramının Türkiye pratiğindeki anlamı ele alınmıştır. Bu çerçevede birbiriyle yakın ilişki içinde olan sanayileşme, modernleşme, Batılılaşma, çağdaşlaşma, muasır medeniyetler seviyesine ulaşma kavram/söylemleri ile bütünsel olarak ele alınacak olan kalkınma kavramı arasındaki ilişki Türkiye özelinde değerlendirilmiştir. Sonrasında ise köy enstitülerinin kuruluşları, eğitim programları ve amaçları dâhilinde ele alınmıştır. Son olarak da kalkınma kavramının enstitüler kapsamındaki anlamı ekonomik ve toplumsal kalkınma çerçevesinde incelenerek; ekonomik ve toplumsal açılardan enstitülerden beklenen kalkınma ivmesi analiz edilecektir.

Köy Enstitüleri 1954 yılında tek parti yönetiminden sonra öğretmen okulları ile birleştirilerek resmi olarak kapatılmışlardır. Ancak bu çalışmanın kapsamı tek parti dönemi ile sınırlıdır. Çünkü modernleşme, Batılılaşma, çağdaşlaşma, muasır medeniyetler seviyesine ulaşma ülküleri ile iç içe geçmiş olan kalkınma hedefi, beraberinde tek parti yönetiminin ideolojisinin köylere/ulusa taşınmasını da içermektedir. Bu sebepten köy enstitülerinden beklenen kalkınma hedefi, tek parti dönemine içkindir. Varlıkları zamanlama olarak çok partili siyasal hayata geçiş dönemi sonrasına da taşan Köy Enstitüleri, bu çalışmanın kapsamı dışında yer almaktadır. Nitel araştırmaya dayanan bu çalışmada, dönemle ilgili süreli yayın ve hatıratlardan da yararlanılarak ilgili literatür taranmıştır. 


\section{KALKINMA KAVRAMI VE TEK PARTİ DÖNEMINDE TÜRKIYYE PRATIĞİNDE ANLAMI}

Kalkınma kavramı, resmi olarak 1940 yılında kurulan ancak geçmişi fiiliyatta 30'lu yıllara kadar götürülebilen köy enstitüleri ile ilişkilendirilmekle ve bu konuda yapılmış pek çok çalışma olmakla birlikte aslında kavram "ekonomi literatüründe" 2. Dünya Savaşı sonrası dönemden itibaren tartışılan, üzerine çalışmalar yapılan, teoriler geliştirilen bir kavram olma özelliği taşır. Kavramın ekonomiyi de aşan bir biçimde toplumsal boyutu ile birlikte ele alınması ve bu bakımdan bir dönüşüm geçirmesi için ise 1970 sonrasını beklemek gerekecektir.

Şu durumda, henüz kalkınma kavramın kendisi bile yokken ya da var olduğu ilk dönemde salt ekonomik anlamda ele alınırken, "köy enstitüleri ile kalkınma; hele ki toplumsal kalkınma ilişkisinden bahsetmek anakronizme düşmek anlamına mı gelir?", "böyle bir ilişki kurmak doğru mudur?" sorularının sorulması gerekir. Bu çalışmanın daha başında hemen bu sorunun cevabını vermeye çalışmak, aslında bu çalışmanın konusunu ortaya koymak anlamına gelecektir. Şöyle ki; aşağıda kavramın anlamı, gelişimi ve içeriği incelenirken de görüleceği üzere, her ne kadar kalkınma kavramı tarihsel süreçte köy enstitülerinden daha sonra ortaya çıkmış olsa da, enstitülerinin kuruluş amacı, çalışmaları ve tek parti yönetiminin onlardan beklediği sosyoekonomik çıktılar göz önünde bulundurulduğunda, kurulan bu ilişkinin, doğru bir tanımlama ve kavram seçimi ile yapıldığı söylenebilir. Bu yargıyı ortaya koyabilmek için ise hem kalkınma kavramının hem de köy enstitülerinin analiz edilmesi gerekir.

Kalkınma kavramının zihinlerde yarattığı ilk imaj çoğunlukla ekonomi odaklıdır. Nitekim kalkınma kavramı ilk önce ekonomik anlamda ele alınan bir kavram olarak II. Dünya Savaşı sonrası dönemde kullanılmaya ve tartışılmaya başlanmıştır. Ekonomik anlamda kalkınma, en kısa anlamıyla "daha fazla refah" demektir ve bu sebepten de "ekonomik kalkınmanın önemi, bireylerin ve toplumun refahındaki artışa yaptığ katkıdan kaynaklanır" (Işık, 2009:853-854). Ekonomik anlamda kalkınma, "büyüme" olarak da ifade edebileceğimiz; "ekonomik üretim, yatırım, dış ticaret, gelir istihdam, sermaye donanımı, servet, doğal kaynak düzeyi gibi bütün sayısal değerlerin artış göstermesidir" (Tolunay ve Akyol, 2006:118).

Ekonomik kalkınma anlamında büyüme, sayısal verilerdeki olumlu kabul edilen artışla birlikte, "bir ülkenin üretim kapasitesini genişletmesi için kullandığı araçlarla ilgili bir kavramdır" (Erbay, 2013:7). Ancak 1970'lerden itibaren kalkınmaya yönelik bu salt ekonomik yaklaşım terkedilirken, kalkınma kavramı yeni anlamıyla "rakamsal ifadelerin yetersizliklerine çözüm olarak geliştirilmiş", "büyüme ve gelişme kavramlarının ötesinde kendine yeni bir inceleme konusu oluşturmuştur" (Erbay, 2013:1). Bu sebepten kalkınma, ekonomi ile ilintili olmakla birlikte, salt ekonomik olmayan başka süreçleri ya da amaçları da bünyesinde barındırabilir. "Örneğin: ... Kalkınma; geleneksel toplumun, gelişmiş batı uluslarının sahip olduğu toplumsal ve teknolojik yapıya topluca dönüş̧ürülmesi olarak anlaşılabilir. Kalkınma; insanların ve toplumların kendilerine güvenli bir gelecek kurabilmelerinin geliştirilmesi ve desteklenmesi olarak düşünülebilir" (Oakley ve Gerforth, 1985'den akt.: Tolunay ve Akyol, 2006:119).

Nitekim kalkınma kavramı, 1970’lerden itibaren de "ekonomik büyüme ile insani gelişme arasındaki ilişkiye ithafen...insani, sosyal, kültürel, çevresel boyutları da" (Kubar, 2016:66) kapsamına alan daha geniş bir perspektiften ele alınmaya başlanmıştır.

Ekonomik anlamda refah artırıcı yönüyle ele alınan kalkınma, toplumsal yönü ile "sosyal yaşam koşullarının iyileştirilmesi için yapılan ve ă̆ırlıklı olarak hizmet yönü ă̆ır basan... sağllk, eğitim, alt yapı, şehirleşme, çevre sorunlarl gibi konuları" içerirken, "insan kalkınması" ise "bireysel ve toplumsal olarak tüm insanların, sahip oldukları potansiyellerini kalkınma için kullanmaları"nı içermektedir (Oakley ve Gerforth, 1985'den akt.: Tolunay ve Akyol, 2006:119).

Kalkınma kavramı literatürde "çok yönlü çaba gerektiren uzun dönemli ve merkezinde insanın yer aldı̆g bir süreç olarak ifade edilmektedir" (Kubar, 2016:65). Bu yeni ve daha geniş kapsamıyla kalkınma kavramı; "üretim faktörlerinin yeni bir birleşimi veya yeni bir üretim fonksiyonu ile emeğin veriminin artırllması, alışkanlıklarda, davranışlarda ve zihniyette bir değişimi ifade etmektedir" (Kubar, 2016:94). İşte burada sözü geçen değişim boyutu, eğitim ile sağlanabilmekte ve bu da kalkınma ile köy enstitüleri arasında kurulan ilişkiyi doğrular görünmektedir.

Burada söz konusu değişim aslında az gelişmiş ülkeler için geçerli olan bir değişimdir denilebilir. Çünkü önce ekonomik sonra da toplumsal boyutları içeren kalkınma kavramı ilk olarak gelişmiş ülkelerden ziyade, gelişmekte ve az gelişmiş ülkelerle ilgili olarak kullanılmaya başlanmıştır. Azgelişmiş ülkelerin ekonomisinin yoğunlukla tarıma dayanması ve bu ülkelerdeki kırsal nüfusun yoğunluğu, kırsal kalkınma ile ilgili özel çalışmaların gelişmesine yol açmıştır. Aslında "kırsal kalkınma, geniş anlamda kırsal toplumların gelişmiş 
toplum statüsüne dönüştürüldüğü bir süreç olarak algılanırsa" (Tolunay ve Akyol, 2006:123), buradaki kırsal kalkınmanın az gelişmiş ülkelerdeki kalkınma anlamına geldiği de söylenebilir. Nitekim bu çalışmanın temel savlarından birisi de Türkiye örneğinde kırsal kalkınmanın, ulusal kalkınma anlamına geldiğidir.

Kalkınma kavramı azgelişmişliğe işaret eden bir kavramdır ve "temel amaç az gelişmiş ve gelişmekte olan ülkeler için kalkınma, gelişmiş ülkeler içinse kalkınmanın sürdürülebilir kılınmasıdır" (Kubar, 2016:65). Bu bağlamda kalkınma kavramı "daha çok az gelişmiş ülkelerin yapısal sorunlarının çözülmesine yönelik uğraşları" (Tolunay ve Akyol, 2006:120) kapsar. Azgelişmiş ülkelerdeki kalkınma (Tolunay ve Akyol, 2006:121);

\begin{abstract}
"bir taraftan kaynakların etkin bir şekilde kullanılması, üretim hayatının geliştirilmesi, sanayileşmenin sağlanması, teknolojik ilerlemenin hızlandırılması gibi temel ekonomik konular üzerinde yoğunlaşırken, diğer taraftan tarımsal verimliliğin artırılmasl, altyapı olanaklarının geliştirilmesi ve ülke insanlarının ĕgitim, beslenme ve sağlık sorunlarının çözülmesini gerektirmektedir"
\end{abstract}

Sonuç olarak kalkınmanın; ekonomik ve sosyal boyutları olan karmaşık süreçleri içeren ve daha ziyade azgelişmişliğe vurgu yapan bir kavram olduğu söylenebilir. 1950-1970 arasında geçerli olan kalkınmaekonomik büyüme eşliği/eşitliği, zaman içerisinde yerini, bütünlüklü bir anlayışa bırakmıştır. "Bütünsel kalkınma olgusu... sosyal, siyasi ve psikolojik etmenleri de içine alarak topyekûn bir düzenlemeyi ifade etmektedir" (Erbay, 2013:22).

Günümüzde kalkınma kavramı hem "kişi başına düşen milli gelirin ve diğer ekonomik göstergelerin artışı" hem de "geleneksel tarımsal toplumdan sanayileşmiş çağdaş topluma geçiş olarak tanımlanan toplumsal değişme"yi içeren bir kavram olarak ele alınmaktadır (Çakmak, 2008:37). Buna göre kalkınma kavramı ekonomik anlamda büyümeyi de içeren ama aynı zamanda bu büyümeye imkân tanıyacak insan, toplum ve çevresel gelişimi de dikkate alan yani sosyo-kültürel dinamikleri dişlamayan daha geniş perspektifli ve bütünsellik içeren bir kavramdir.

Kalkınma kavramının tek parti döneminde anlamına baktığımızda, daha önce de ifade edildiği üzere söz konusu kavram köy enstitülerinin kurulduğu dönemde dünyada ne ekonomi ne de genel anlamda sosyal bilimler disiplininde henüz kullanılmamaktadır. Bunun için II. Dünya Savaşı sonrası dönemi beklemek gerekecektir. Ancak dönem itibariyle Türkiye'de hem ekonomik hem de toplumsal boyutu ile kalkınmayı içeren; çağdaşlaşma, muasır medeniyetler seviyesine ulaşma, modernleşme gibi kavram ve söylemlerin kullanıldığı bilinmektedir.

"Sanayileşme, büyüme, gelişme, yapısal değişim ve hatta modernleşme anlamı da atfedilen kalkınma kavramı, toplumların değişme ve gelişme süreçlerine uygun olarak farkl dönemlerde değişik iç̧erik ve anlamlarda kullanılmıştı" (Erbay, 2013:4). Kalkınma, siyasal iktidarların "toplumun yapısını değiş̧tirme girişimidir" (Adem'den akt.: Çakmak, 2008:36). Azgeliş̧ş̧̧lik, geleneksel yapının dönüştürülmesi, büyüme kavramları sarmalındaki bu karmaşık bütün bizi Türkiye özelinde başka bir kavrama; modernleşme kavramına ve yine onunla ilintili çağdaşlaşma, Batılılaşma kavramlarına ve muasır medeniyeler seviyesi söylemine yöneltir. "Modernleşme... kalkınma olgusunun belkemiğini oluşturan bir sosyal bilim konseptidir". Modernleşmenin toplumsal yapıyı yeniden düzenlerken, geleneksel karşısındaki konumu, geleneksel yapıyı zayıflatması, onu "kalkınma sürecinin temel taşı" haline getirmektedir (Erbay, 2013:8).

Kalkınma ile modernleşme arasındaki yakın bağlantıyı da göz önünde bulundurarak, Cumhuriyet tarihini önceleyen modernleşme tecrübesinin geç Osmanlı döneminden itibaren eğitim yoluyla sağlanmaya çalışıldığı bilgisinden hareket ederek, köy enstitülerini de bu kapsamda yani; modernleşme-kalkınma kapsamında değerlendirmek gerekir. "Yaklaşık bir buçuk asırdan beri devam eden Batılılaşma hareketleri içerisinde, eğitim kurumlar ile öğretmenlerin özel bir yeri olmuş ve eğitim, toplumun yapısını değişstiren ve topluma daha iyi yaşama seviyesi sağlayan dinamik bir sosyal kuvvet olarak kabul edilmiştir" (Çakmak, 2008:34). Nitekim Türkiye'de tek parti dönemi boyunca köy enstitüleri modernleşme, çağdaşlaşma, Batılılaşma projesinin bir aracı olarak görülmüş ve bu kavramlara günümüzün ifadesiyle denk gelen olgu; aslında hem iktisaden hem de sosyal, kültürel ve siyasal yönlerden "kalkınma" kavramı olmuştur.

Kalkınma kavramının az gelişmişlikle olan ilişkisi ve içerdiği bütünsellik, karşımıza eğitim kavramını çıkarmaktadır. "Bir ülkenin kalkınmışlık düzeyini belirlemede kullanılan en önemli ölçütlerden biri, o ülkenin sahip olduğu insan kaynaklarının niteliğidir" (Taş ve Yenilmez, 2008:162). Çünkü bir ülkedeki kalkınmanın başarısı, esas olarak o ülkedeki iş gücünün, "çalışabilen nüfusun güçlü yapısına bağlıdır" (Erbay, 2013:1). Bu sebepten birer "eğitim" kurumu olan köy enstitülerinin tek başına bir okullaşma çabasının çok ötesinde anlam 
taşıyan ve hem ekonomik hem de toplumsal boyutları ile kalkınma için gereken nitelikli iş gücünü sağlamayı hedefleyen bir proje olarak geliştirildiğini söylemek mümkündür.

"Sosyo-ekonomik gelişmenin en önemli itici gücü ve verimlilik artışının en önemli unsuru, toplumun eğitim düzeyidir" (Çakmak, 2008:35). Tek parti yöneticileri her ne kadar sosyo-ekonomik gelişme ya da henüz icat edilmemiş olan kalkınma kavramını kullanmamış olsalar da, hem Osmanlı tecrübesi hem de mevcut sermeye birikimi koşullarında, eğitimin bu gücünden faydalanma zaruretini fark etmişlerdir. Şüphesiz bu zaruret, dönem itibariyle ülkenin sahip olduğu maddi koşullarla da ilgilidir.

Tek parti yönetiminin 1940 yılı koşullarında kalkınma hamlesini gerçekleştirecek, nitelikli iş gücünü sağlayacak yeterli sayıda okulu ve öğretmeni yoktur. 1940'ların Türkiyesi'nde 40.000 köyden, sadece 5.000'inde ilkokul bulunmaktadır (Aydın, 1997:28). Anadolu'da şehirlerde \%78, köylerde ise \%90'a varan bir okur yazar olmayan kitle söz konusudur (Kartal, 2008:23). Nitekim Köy Enstitüleri Kanunu'nun çıkarılma gerekçesi olarak ülkedeki 1935 yılı nüfus sayımı sonuçlarının ortaya çıkardığı tablo gösterilmiştir. Buna göre, Türkiye'de erkeklerin \%76,7'si, kadınların ise \% 91,8'i okuma yazma bilmemektedir. Nüfusun \%80'ine tekabül eden, 12.5 milyon köylünün yaşamakta olduğu 40.000 köyün, sadece \%26'sında köy çocukları okula gitmektedir. Sayım sonuçları köylerde ilköğretimin bir an önce yayılmasını bir "milli dava" olarak görülmesine yol açmıştır (KEÇEV, 2000:32-33). Ancak her ne kadar köy enstitüleri kanununda enstitülerin kuruluş gerekçesi olarak, okuryazar oranlarındaki düşüklük gösterilse de, aşağıda da inceleneceği üzere, köy enstitüleri tek parti yönetimi açısından bir okullaşma hareketinden çok daha ötesini ifade etmiştir. Hem ekonomik hem de toplumsal boyutu ile bu eğitim hamlesi aracılı̆̆ıyla ulusal kalkınmayı hedefleyen bir anlayış, beklenti ve enstitülerde de buna yönelik faaliyetler söz konusudur.

Sonuç olarak, kalkınma kavramın tek parti döneminde Türkiye pratiğinde anlamının modernleşme/çağdaşlaşma/Batılılaşma kavramları ile de ifade edilen kavram setlerine ve muasır medeniyetler seviyesine ulaşma söylemine denk geldiği, köy enstitülerinin kurulduğu dönemde ülke nüfusunun \%80'inden fazlasının köylerde yaşadığı göz önünde bulundurulunca, "halk" olgusunun büyük oranda "köylü" anlamına geldiği söylenebilir. Dolayısıyla köyde başlatılacak bir kalkınma hamlesi de asıl olarak ulusal bir kalkınma hedeflenmiştir.

\section{KÖY ENSTITÜLERI}

Köy Enstitüleri 17 Nisan 1940 tarihinde 3803 Sayılı “Köy Enstitüleri Kanunu” ile Milli Eğitim Bakanlığı’na bağlı olarak kurulmuşlardır. Ancak Cumhuriyet dönemini de önceleyen köyde eğitim düşüncesi, Cumhuriyetin kuruluşunun ardından özellikle de 1930'lar Türkiyesinde daha da sistematikleşerek hız kazanmış ve sonuç itibariyle 1937 yılında, İzmir-Kızılçullu ve Eskişehir-Mahmudiye'de ve 1938 yılında Edirne-Karaağaç ve Kastamonu-Gölköy'de açılan köy öğretmen okulları (Saydur ve Yılmaz, 1994:23) köy enstitülerinin fiiliyatta ilk örnekleri olmuştur. Köy Enstitüleri Kanunu'nun çıkması ile bu köy öğretmen okulları köy enstitüleri adı altında eğitime devam ederek, ilk mezunlarını vermiştir. Hatta bu yüzden Kirby (1962:137), ilk köy öğretmen okulunu "Proto-Köy Enstitüsü” olarak adlandırmıştır. Köy Enstitülerinin ilk örneği olan bu köy öğretmen okulları ile aynen köy enstitülerinde olduğu gibi marangozluk, demircilik, tarım, sağlık eğitimleri almış öğretmenlerin, köy çocuklarına 5 yıllık bir eğitim verilmesi planlanmıştır (Bayram, 1999:10).

Milli Eğitim Bakanlığı tarafından belirlenmiş kesin bir programı olmayan ve kuruldukları bölgenin coğrafyasına, iklimine göre eğitim yapılan bu okullar, 1940 yılına kadar köy öğretmen okulu adı altında, öğrencilere hem teorik hem de pratik bilgiler aktarmışlardır. 5 yıllık bir eğitim vermek üzere 1940'da kurulan köy enstitülerinin ilk mezunlarını 1942'de vermesi de bu sebepten kaynaklanmıştır.

Kanun ile köy öğretmeni ve köye yarayan diğer meslek erbabını yetiştirmek için, ziraat işlerine elverişli arazisi bulunan yerlerde köy enstitüleri açılması, köy okullarını bitiren sıhhatli köylü çocuklarından başarılı olanların köy öğretmeni olarak, köylere 20 lira maaşla atanması ve 20 sene boyunca, bakanlıkça tayin edilecek köylerde çalışmaları karara bağlanmıştır. Ayrıca, enstitü öğrencileri arasında öğretmenlikte başarılı olamayacağı düşünülenlerin, çeşitli konularda meslek öğrenerek birer meslek erbabı olmaları kararı alınmış ve bu okullara bu sebepten öğretmen okulu değil de enstitü ismi uygun görüşmüştür. Köy enstitüsü mezunu öğretmenlerin, köylerdeki köy çocukları ile birlikte köylüleri de kapsayan eğitim işlerinin içerisinde; ziraat işlerinin bilimsel tekniklere göre yapılmasını sağlamak için tarladan elde edilecek gelir kendisine kalmak üzere, kendilerine verilen tarlada köylülere rehberlik etmek gibi görevleri de bulunmaktadır. 
Köy öğretmeninin tayin edileceği okulların binaları ile öğretmen evlerinin yapımının Maarif Vekilliği'nce verilecek planlara göre, bölge ilköğretim müfettişi ile gezici başöğretmenin denetimi altında köy ihtiyar heyetleri tarafından yani köylüler tarafından yapılması ile bu okul binalarının tamiri ve okulun daimi masraflarının temin edilmesi de köy ihtiyar heyetinin sorumluluğuna bırakılmıştır. Bunların dışında kanun ile köy öğretmeninin faaliyetlerinin, gezici başöğretmen ve ilköğretim müfettişleri tarafından teftiş edilmesi de karara bağlanmıştır (http://www.resmigazete.gov.tr/arsiv/4491,pdf).

Kanunun çıktığı tarihten itibaren 15 yıl içinde açılması planlanan 22 köy enstitüsü ile 17.000 ila 20.000 arasında köy öğretmeninin ve köyler için gerekli görülen sağlık memuru gibi diğer köy erbabının yetiştirilmesi hedeflenmiştir (KEÇEV, 2000:38). Bu hedefleri gerçekleştirmek için, harekete geçilerek enstitüler kurulmaya başlanmış ve de kısa bir süre içerisinde köy enstitülerinin sayısı 21'e ulaşmıştır. Bunlardan ilk dördü 1940 öncesinde kurulmuş olup, köy enstitülerine dönüştürülen mevcut köy öğretmen okuludur. Diğerlerinin kuruluş yılları da yanlarında gösterilmiştir (Türkoğlu, 1997:176-177);

1. Eskişehir-Çifteler Köy Enstitüsü,

2. İzmir-Kızılçullu Köy Enstitüsü,

3. Kırklareli, Lüleburgaz-Kepirtepe Köy Enstitüsü

4. Kastamonu-Gölköy Köy Enstitüsü

5. Adana-Haruniye Düziçi Köy Enstitüsü, (1940)

6. İzmit, Adapazar1-Arifiye Köy Enstitüsü, (1940)

7. Antalya-Aksu Köy Enstitüsü, (1940)

8. Balıkesir-Savaştepe Köy Enstitüsü, (1940)

9. Isparta-Gönen Köy Enstitüsü, (1940)

10. Kars-C1lavuz Köy Enstitüsü, (1940)

11. Malatya-Akçadağ Köy Enstitüsü, (1940)

12. Kayseri-Pazarören Köy Enstitüsü, (1940)

13. Samsun-Akpınar Köy Enstitüsü (1940)

14. Trabzon-Beşikdüzü Köy Enstitüsü (1940)

15. Ankara- Hasanoğlan Yüksek Köy Enstitüsü, (1941)

16. Konya-İvriz Köy Enstitüsü, (1941)

17. Sivas-Yıldızeli Köy Enstitüsü, (1942)

18. Erzurum-Pulur Köy Enstitüsü, (1942)

19. Aydın-Ortaklar Köy Enstitüsü, (1944)

20. Diyarbakır-Dicle Köy Enstitüsü, (1944)

21. Van-Ernis Köy Enstitüsü'dür (1948)

Dikkat edilirse bu enstitülerin ülkenin her bölgesine yayılacak biçimde kuruldukları görülür. Her biri kendi kurulduğu bölgeden sorumlu birer üs konumunda olan enstitüler, kendileriyle benzer amaçlarla kurulmuş ve kendilerine bağlı köy eğitmen kursları ${ }^{1}$ ile birlikte, başlı başına bir sistem oluşturmuşlardır. Açılan her bir enstitü, bir merkez olarak çevresindeki şehirlerde bulunan köy çocuklarının ve köylülerin eğitiminden sorumlu olmuştur. Açılan her bir yeni enstitü ile öğrenciler köylerine daha yakın olan enstitülere gönderilmişlerdir (Türkoğlu, 1997:175). Bu sebepten öğretmen adayı olarak seçilen öğrenciler, kendi köylerinin bölgesel, iklimsel koşullarına yakın enstitülere yönlendirilmişler, deniz kenarındaki köylerde yaşayan ve mezun olunca yine bu köylere tayin edilecek olan öğrenciler denizcilik ve deniz üretimi üzerine uzmanlaşan enstitülere

1 Köy Enstitüleri mantığına göre, enstitülerden daha önce, nüfusu 150den az olan köylerde 3 yıllık bir eğitim vermek için köylü çocukları dâhil tüm köylünün eğitimi için kurulan Köy Eğitmen Kursları ile ilgili ayrıntılı bilgi için bkz.: ERDEM, Çiğdem (2008), “Cumhuriyet Yönetiminin 1930’lu Yıllarda Köyde ve Köylülükte 'Dönüşüm'ü Gerçekleştirme İsteğinin Bir Aracı Olarak 'Köy Ĕ̆itmen Kursları”, Gazi Üniversitesi İIBF Dergisi, S.10(3), ss.187-200. 
gönderilmişlerdir. Buna göre her biri birer üs olan köy enstitülerine bağl1 olan şehirler şu şekilde belirlenmiştir (Türkoğlu, 1997:176-177);

- Eskişehir-Çifteler Köy Enstitüsü: Afyon, Kütahya, Uşak, Konya

- İzmir-Kızılçullu Köy Enstitüsü: Manisa, Denizli, Aydın

- Kırklareli, Lüleburgaz Kepirtepe Köy Enstitüsü: Edirne, Tekirdağ

- Kastamonu-Gölköy Köy Enstitüsü: Çankırı, Çorum, Zonguldak, Sinop

- Adana-Haruniye Düziçi Köy Enstitüsü: Maraş, Gaziantep

- İzmit, Adapazarl- Arifiye Köy Enstitüsü: Bursa, Bilecik, İstanbul, Bolu

- Antalya-Aksu Köy Enstitüsü: Muğla, Mersin

- Balıkesir-Savaştepe Köy Enstitüsü: Çanakkale

- Isparta-Gönen Köy Enstitüsü: Burdur

- Kars-Cilavuz Köy Enstitüsü: Artvin, Ağr1

- Malatya-Akçadăg Köy Enstitüsü: Tunceli, Elazı̆̆

- Kayseri-Pazarören Köy Enstitüsü: Yozgat, Kırşehir, Niğde

- Samsun-Ladik Akpinar Köy Enstitüsü: Amasya, Tokat

- Trabzon-Beşikdüzü Köy Enstitüsü: Ordu, Giresun, Gümüşhane, Rize

- Ankara-Hasanoğlan Köy Enstitüsü: Ankara, Çankırı

- Konya-İvriz Köy Enstitüsü: Nevşehir, Niğde

- Sivas-Ylldızeli Köy Enstitüsü: Erzincan

- Erzurum-Pulur Köy Enstitüsü: Bingöl

- Aydın-Ortaklar Köy Enstitüsü: Denizli

- Diyarbakır-Ergani Dicle Köy Enstitüsü: Urfa, Mardin, Bitlis

- Van-Ernis Köy Enstitüsü: Hakkâri.

Öte yandan köy enstitülerinin fiziki yapısı ile ulusal kalkınma ülküsü arasında da bir bağ kurmak mümkündür. Şöyle ki her bir köy enstitüsü, ulusal kalkınma ülküsünün içinde barındırdığı ekonomik ve toplumsal yönden kalkınmış köy/ülke kurgusuna göre inşa edilmişlerdir. İncelendiğinde her bir köy enstitüsünün "üretim" temelli kuruldukları görülecektir, bu bakımdan yatılı birer okul olan enstitülerin bu yöndeki ihtiyaçları dışında her birinde revir, fırın, kooperatif, ahır, ağıl, kümes, arılık, balıkhane, su deposu, tahıl deposu, erzak deposu, havuz, elektrik santrali, bağ, bahçe, tarla, fidanlık koruluk, çiçeklik, kitaplık, laboratuvar, atölyeler (demirci, marangoz, iş atölyeleri), müzik salonu, toplantı salonu, tiyatro salonu, spor tesisleri, berber, terzihane, PTT merkezleri gibi birimler oluşturulmuştur (Candoğan, 1990:38-39; Türkoğlu, 1997:189-189; Öner, 1979:24). Nitekim İsmail Hakk1 Tonguç, bütün bu birimleri içinde bulunduran köy enstitülerinin "modern birer köy gibi” kurulduklarını, "her şeyi tamam ideal, bir köy örneğì" olduklarını ifade etmiştir (Tonguç, 1948:479).

Sayılan bu birimlerin çok büyük bir kısmı, hem eğitim kapsamında hem de sermaye yokluğundan enstitülere yeterince kaynak aktarılamamasından ötürü bizzat öğrenciler tarafindan işletilmişlerdir. Enstitü bünyesi içerisinde yer alan bütün bu birimlere bakıldığında enstitülerin "dlş̧arlya hiç ihtiyaç göstermeyecek her türlü alt ve üst yapr tesisleri" (Öner, 1979:25) ile otarşik bir yapı kurarak ulusal kalkınma ülküsünün de temelini oluşturan kendi kendilerine yeterliliği hedeflediği söylenebilir. Bu bakımdan köy enstitülerinin arması da bu kendine yeterli, ideal kalkınmış köy/ülke hededini göstermesi bakımından dikkat çekicidir.

Armaya bakınca dikkati çeken ilk unsur, Türk bayrağını andıran bir ay yıldızın çevrelediği bir köydür. Ancak bu köy son derece düzenli ve daha ilk bakışta kalkınmış bir köy görüntüsü çizmektedir. Çünkü köyün içinden yükselen bir elektrik santralinin direği olduğu gibi, yeşillikler içinde resmedilen köye uzanan nizami bir yol da vardır. Söz konusu elektrik santralinin direği ve yol ekonomik anlamda kalkınmayı, buna karşlık nizam, düzgün çevre ve yaşam koşulları da toplumsal anlamda kalkınmayı işaret etmektedir. 
Her enstitüye uygulamalı eğitimi gerçekleştirip, ürün alabilmek için 2000-3000 dekara ulaşan arazi verilmiştir (Tonguç, 1940:2). Her bakımdan büyük kapsamlı düşünülen köy enstitülerinin içinde barındırdığı insan sayısı da buna göre büyüktür; idareciler, öğretmenler, ustalar ve öğrencilerle beraber, bir enstitü 1000 civarında insanı barındırmıştır.

Enstitülerden 1946 yılına kadar yaklaşık 17.000 öğretmen ve 7300 sağlı memuru mezun olmuştur (Kartal, 2008:26). Tek partili yönetimden sonra da varlıklarını sürdüren köy enstitüleri, 1954 y1lında Demokrat Parti döneminde öğretmen okulları ile birleştirilmek suretiyle kapatılmışlardır.

\section{ULUSAL KAKINMANIN BIRR ARACI OLARAK KÖY ENSTITÜLERİ}

Köy enstitülerinde, köylerden alınan öğrenciler köy hayatının gerektirdiği biçimde "tam donanımlı olarak" yetiştirilmek üzere eğitildikten sonra, "tekrar köylerine, geride kalan insanları eğiterek yöre dolayısıla ülke kalkınmasına katkıda" bulunmak üzere gönderilmişlerdir (Kartal, 2008:23). Köy enstitüleri "toplumu bütün olarak gören ve ekonomik, sosyal ve kültürel yönlerden gelişmesini sağlama amacıyla" başlatılmış bir "kalkınma hareketidir" (Bilir, 2003:1).

"Köy Enstitülerini Cumhuriyetin eserleri içinde en klymetlisi ve en sevgilisi saylyorum" (Kut, 2000:33) diyen dönemin Cumhurbaşkanı İsmet İnönü nezdinde, bu kurumların söz konusu kıymetinin, kalkınma yani cumhuriyetin, çağdaşlaşma, Batılılaşma, sanayileşme (ekonomik anlamda kalkınma), kısaca muasır medeniyetler seviyesine ulaşma ülküsünden kaynaklandığı söylemek mümkündür.

3803 sayılı kanuna göre, köylerdeki okuma yazma sorununa bir çözüm üretmek için köy öğretmeni yetiştirmek üzere açılmış eğitim-öğretim kurumları olarak görünen köy enstitülerinin amaçları arasında ve tek parti yönetimin bu kurumlardan beklentileri arasında, şüphesiz böyle bir hedef de olmakla ve bu hedefle ulusal kalkınma arasında bir ilişki kurmak mümkün olmakla birlikte, enstitülerin yukarıdaki paragrafta ifade edilen kıymetinin arkasında çok daha geniş hedeflerin olduğunu söylemek mümkündür. Köy enstitülerinin kurum olarak ülke sathında yayılma genişliği, bu kurumlara sağlanan/sağlanmaya çalışılan imkânlar, bu öğretmen okullarında verilen eğitim programlarının niteliği (Maarif Vekilliği, 1943), köy enstitüsü mezunu köy öğretmenlerine yüklenen görevler incelendiğinde, tek parti yönetiminin köy enstitüleri ile köy çocukları ile birlikte bütün bir köyün eğitimini hedeflediği ortaya çıkmaktadır. Başka bir deyişle burada öğretimi aşan boyutuyla bir eğitim söz konusu olduğu gibi bu eğitimin kapsamı içerisine köy çocukları ile birlikte bütün bir köy ve köylü girmektedir. Yine başka bir deyişle, dönem itibariyle Türkiye'de köylülügüun toplam nüfus içindeki ağırlığı düşünüldüğünde aslında enstitülü öğretmenden beklenen "neredeyse" bütün bir ulusu eğitmektir. Bu eğitimin yönü ise, muasır medeniyetler seviyesine ulaşma ülküsü ve onunla ilintili olan modernleşme ve kalkınma hedefleri doğrultusundadır.

Bu kalkınma, köyün ve köylünün, hem ekonomik, hem de toplumsal açıdan kalkınması ile toptan bir ulusal kalkınmayı içermektedir. Köy enstitüleri, "öğretmen yetiştirilmesi kadar nüfusun büyük bölümü köyde yaşayan toplumun kalkınması için önemli bir ivme olmuş" (Kartal, 2008:24) ya da en azından bu hedefle kurulmuşlardır. Ekonomik kalkınma sayesinde, köylerin daha üretken bir hale gelmesi, verimliğin ve ürün çeşitliliğinin artırılması hedeflenirken, toplumsal kalkınma ile modernleşme kapsamında Cumhuriyetin değer ve ilkelerinin köylere götürülmesi ve bu sayede "Cumhuriyet köyleri” (Tonguç, 1997:414)'nin inşa edilmesi hedeflenmiştir.

Hasan Ali Yücel'in ifadesiyle, “Birer insan fabrikasl” (Ulus, 1940:1) olarak görülen köy enstitüleri ile köylünün -ve aslında köylünün ulus içerisindeki niceliği düşünülecek olursa bu cümleyi ulusun şeklinde de kurmak mümkündür- "yeni ekonomik, sosyal, siyasal ve kültürel alışkanlıklar kazanarak değiş(mesi)" (Türkoğlu, 1997:138) hedeflenmiştir. Köy enstitülerinin, "kırsal alanı kalkındırmak", "köylüyü üretici durumuna getirmek" (Kartal, 2008:25) amac1, köy ve köylünün toplam nüfus içindeki yeri düşünülünce, ulusal boyutta topyekûn kalkınma anlamına da gelmektedir.

\subsection{Köy Enstitüleri ve Ekonomik Kalkınma}

Köy Enstitülerinin kuruluş amaçlarından birisinin, "birer üretici güç olarak köy halkını eğitme ve onların bölgenin kalkınmasında önemli (bir) özne” (Aykaç vd., 2018:187) olmalarını sağlamak suretiyle köyde ve makro düzeyde tüm ülkede ekonomik bir kalkınmayı sağlamak olduğu söylenebilir. Tek parti yönetimi dönemin ekonomik koşulları nedeniyle ya da daha açık bir ifadeyle sermaye yokluğundan dolayı, köye tam donanımlı bir öğretmen göndererek üretim miktarını, kalitesini ve çeşitliliğini artırmak suretiyle köyü ve onun üzerinden de genel olarak ulusal bir ekonomik kalkınmayı sağlamayı hedeflemiştir. 
Köy enstitülerinde öğrencilere kültür ve öğretmenlik bilgisini içeren derslerin yanı sıra yoğun biçimde iş bilgisini içeren dersler ve bu derslerin uygulamalarının gösterilme sebebi de budur. Enstitülerde Cumartesi yarım gün dâhil haftalık 44 saati bulan eğitimin 22 saati kültür derslerine 22 saati de ziraat ve teknik dersleri ile bu derslerin uygulamasına ayrılmıştır (Gedikoğlu, 1971:89).

Enstitülerdeki kültür ve öğretmenlik bilgisi içeren dersler dışındaki iş bilgisi derslerini incelediğimizde, derslerin hem teoride hem de pratikte \%50'sinin bu türden iş bilgisi dersleri olduğunu görürüz (Binbaşıŏlu, 1990:7). Bu derslerin bir kısmı enstitünün kurulduğu bölgenin iklim ve coğrafyasına göre değişmekle birlikte aldıkları derslerin; Tarla Ziraatı, Bahçe Ziraatı, Sanayi Bitkileri Ziraatı, Zootekni, Kümes Hayvanları Bilgisi, Arıcılık ve İpek Böcekçiliği, Balıkçılık ve Su Ürünleri Bilgisi, Köy Demirciliği (nalbantlık, motorculuk), Köy Dülgerliği (marangozluk), Köy Yapıcılığ (tuğlacılık ve kiremitçilik, taşçılık, kireççilik, duvarcılık ve sıvacılık, betonculuk), Köy Ev ve El Sanatları (dikiş-biçki, nakış, örücülük ve ziraat sanatları) derslerini içerdiği görülür (Maarif Vekilliği, 1943:1-2). Çok farklı alanları kapsayan bu iş eğitimi ile köy enstitüsü mezunu öğretmenin, köyüne döndügü zaman bu alanlardaki yenilikleri, bilimsel yöntemleri köylüye aktarmaları ve bu sayede de köyde üretim kalitesini, miktarını ve çeşitliliğini artırması beklenmiştir.

Enstitülere öğrenci alırken öğrencilerde akademik başarı dışında sağlıklı ve gürbüz olmaları gibi fiziksel bazı şartların aranması (Gedikoğlu, 1971:58) yine bu ekonomik kalkınma hedefi ile paraleldir. Çünkü hem eğitimi sırasında sağlıklı olmayan bir öğrencinin oldukça yoğun bir bedensel çalışmayı gerektiren bu eğitimde başarılı olması hem de mezun olduktan sonra aldığı bu iş eğitimini pratiğe döküp kendisine verilen tarlada verimli olup köylüye örnek olması mümkün değildir.

Köy enstitüsü kanunu ile öğretmenlere verilen uygulama tarlasının üzerinde durmak, köy enstitüleri üzerinden ulusal kalkınma hedefini açıklama anlamında önemlidir. Köy Enstitüsü mezunu öğretmenlere 20 lira bir ücret ödenmesi kararı alınmıştır. Ancak anlaşılan bu ücret dönemin ekonomik koşulları itibariyle çok yeterli bir ücret değildir. Bu sebeple öğretmenlere geliri kendilerine kalmak suretiyle ekip, biçmek, işlemek üzere bir de tarla verilmiştir. Ancak burada önemli olan bu tarlanın aynı zamanda bir "eğitim tarlası" olmasıdır. Enstitülü öğretmenin yukarıda saydığımız iş dersleri kapsamında eğitimi sırasında öğrendiği modern tarım tekniklerini, hayvan bakımını, ürün çeşitlendirme bilgisini ya da en uygun ürün çeşidini seçmeyi köylülere bu tarla üzerinden öğretmesi beklenmiştir. Köy öğretmeninin toprăğ ekip biçmek suretiyle hem kendi geçimini sağlaması, hem de köylülere enstitüdeki eğitimi sırasında öğrendiği, "modern üretim tekniklerini” içeren yeni bilgileri öğretmesi (Çakır, 1995:38-46) ve böylelikle köylünün "geleneksel üretim yöntemlerinden kurtulup, tarımda ve el sanatlarında çağdaş yöntemleri kullanması hedeflenmişti”" (Yücel, 1997:17).

Köy çocukları için bir öğretmen olmasının çok ötesinde köylüye bir rehber, bir "önder" (Yücel, 1997:303) olması için gönderilen köy öğretmenlerinin, köylerde ekonomik yönden bir canlanma yaratabilmesi adına kendisine verilen bu tarladaki başarısının önemli olduğu söylenebilir. Çünkü geleneksel yöntemlerle tarlasını işleyen, hayvanına bakan köylünün ikna olması, tarlasında yeni ürünler denemesi, ürün çeşitliliğine gitmesi, öğretmenin bir tür rehberlik ve önderlik sınavına tabi olması demekti ve öğretmenin bu sınavı geçmesi onun başarısına, yani tarladan elde edeceği ekonomik kazancına bağlı idi.

19 Haziran 1942 tarih ve 4274 sayılı Köy Okulları ve Enstitüleri Teşkilat Kanunu'nda köy öğretmeninin görevlerinden birisinin de köy halkını yetiştirme görevi olduğu görülür. Buna göre enstitülü öğretmenin aşağıdaki gibi görevleri bulunmaktadır (KEÇEV, 2000:138);

\begin{abstract}
"Köyün ekonomik hayatın geliştirmek için ziraat, sanat, teknik alanlarında köylülere örnek olabilecek işler yapmak; okullarda sergiler açmak ve diğer münasip yerlerde panayırlar açılmasına yardım etmek, istihsalin artırllması ve ürünlerin kıymetlendirilmesi, köy iş hayatının canlandırllmasiyle ilgili tedbirlerin alınmasında köylülere gereken yardımlarda bulunmak; gidip gelinmesi mümkün yerlerdeki pazar, sergi, panayır, fuar, müze gibi ekonomik hayatın gelişmesiyle ilgili kuruluşlarla halkı ve talebeyi ilgilendirmek, onlarn buraları ziyaret etmelerine kilavuzluk etmek; ormancılı̆̆a ait bilgilerin arttırılmasına çalışmak ve ormanların faydalarını ve korunmalarını anlatmak; kurulmuş köy ormanlarının bakımiyle korunmasında ve yeniden kurulacakların kurulmasinda yardım etmek"
\end{abstract}

Enstitü programlarında, "dere, çay, ırmak, nehir, göl ve denizlerde mevcut balık, sünger, saz gibi unsurların bilimsel şartlara göre üretilmesi ve değerlendirilmesi; arazinin ăgaçlandırılması, çiçekçilik, bataklıların kurutulması, yol yapımı, su kanalı açmak, çorak alanları verimli hale getirmek, çevreye göre yeni bitki çeşitleri üretmek" gibi belirtilen çalışmalar da yine programda yer almıştır (Kartal, 2008:27); 
Enstitülü öğretmene verilen tarla dışında, köylüyü ikna edip onu daha verimli kılma adına enstitü tarafından köylülere fidan, fide, tohumluk buğday, damızlık hayvan ve araç-gereç gibi yardımlar da yapılmıştır. Hatta devlet eliyle makineli tarıma geçiş sağlayacak imkânlar olmadığı için köyde traktör, biçerdöver gibi araçların alımı amacıyla köy öğretmeninin bu araçların ortak alınmasına öncülük yapması da istenmiştir (Türkoğlu, 1997:448). Bunun dişında köye giden öğretmenlere köylerine giderken yanlarında götürmek ve üretim süreçlerinde kullanmak üzere metre, kumpas, demirci mengenesi, testere, çivi sökme manivelası, badana furçası, yağdanlık, çekiç, örs, İngiliz anahtarı, keser, dikiş makinesi, ütü, örgü şişi, dokuma tezgâhı gibi içi iş araç gereçleriyle dolu bir sandik da verilmiştir (Semerci, 1997:167).

Köy öğretmenine verilen aletlerle köyde ve köyün mevcut dönem Türkiye demografisinde, ekonomi-politiğinde taşıdığı önem dolayısıyla bir ulusal kalkınmaya gidilmeye çalışıldığını söylemek, abartılı bir ifade olarak görünebilir. Ancak ilk olarak; köy enstitülerinin tek parti yönetimi tarafindan uzun soluklu bir mücadelenin arac1 olarak görüldügünü unutmamak gerekir. İkinci olarak mevcut dönemde Türkiye açısından yaşanan sermaye kitlığ 1 ya da zaten o vakte kadar sermaye birikimin yeteri ölçüde gerçekleştirilememiş olması ya da daha basit bir ifadeyle Türkiye'nin ileri kapitalist ülke olmak bir yana, merkezin çevresi konumunda olması sebebiyle, ekonomik kalkınmayı tarımda makineleşme ile sağlayacak imkânlarının olmadığı dikkate alınmalıdır. Üçüncü olarak 1929 buhranının süregelen etkileri sebebiyle uluslararası ekonomik konjonktürün sermaye ithal etmeye müsait olmadığının da hatırlanması gerekir. Son olarak da ülkenin durumunu açıklayabilmek adına bu basit görünen bir sandık aletle mi ekonomik kalkınma başlatılacak sorusunu sordurabilecek aletlerin, makinelerin bir kısmının köylülerce daha önce kullanılmadığının da göz önünde bulundurulması gerekir.

1943 tarihli köy enstitüleri eğitim programı kapsamında enstitülerde verilen dersler ile ekonomik kalkınma arasında köylünün üretici kılınması ve verimli olması dışında kurulabilecek bir başka bağ ise küçük üretici olarak köylünün ekonomik örgütlenmesine ilişkindir. Zirai işletmeler ekonomisi ve kooperatifçilik gibi dersler ile "çağdaş bir kalkınma anlayışının ögretmen adaylarına kazandırılması" hedeflenmiştir (Kartal, 2008:26).

Enstitülerden sadece öğretmen yetiştirilmediği köye yarayışlı diğer eleman adı altında çeşitli teknik eleman ve özellikle de köyde çalıştırılmak üzere sağlık memurlarının da yetiştirilmiş olmasının da ekonomik kalkınma ile dolaylı bir ilişkisi olduğunun da ayrıca belirtilmesi gerekir. Enstitülerdeki sağlı memurluğu programı aracılığıyla "hem enstitü ögrencilerinin sağllk ihtiyaçları karşılanırken hem de köylülerin sağlık taramaları yapılmış ve gerekli tedaviler uygulanabilmişti" (Aysal, 2005:276). Bunun anlamı ise ekonomik kalkınma için gereken iş gücünün sağlığının korunarak, verimliliğinin artırılmasıdır.

Sonuç olarak köy enstitüsü mezunu öğretmenlerin her biri köylerine yetişmiş insan gücü olarak gönderilmişlerdir. "Köy Enstitülerinin temel amaçlarının başında gelen Türkiye ekonomisinin eğitim yoluyla kalkındırılması, programın ana eksenini oluşturmuştur" (Aykaç vd., 2018:190). Aldığı eğitimi gerek teorik gerekse de pratik olarak köylülere aktarması beklenen öğretmenin köyünde bir öğretmen, bir rehber, bir önder olarak köyde üretim tekniklerini, sermaye ve teknoloji yokluğunda mümkün mertebe iyileştirmesi beklenmiştir. Bu sayede köylü (Güner, 1963:49);

"hayvanindan iyi döl ve bol ürün almall, toprağa verdiği emeğine karşılık daha fazla mahsul almall, harmanını döven ile değil, motör ile dövmeli, iyi yemeli iyi giymeli, tarlası için yağmur duasına çıkmaktan önce, sulama tesisi yapmayı düşünmeli, geçimini yalnızca topră̆a değil, kümese, kovana, tezgaha ve daha başka çeşit kazanç kaynaklarına bağlamalı, havası güneşi bol, sağlı̆̆a yarayışlı bir meskende oturmalı, evini çıra ışı̆̆ından değil de petrol lambasından kurtarıp elektrikle süslemeli, kasabaya gitmek üzere eşeğine değil, otomobiline binmeli, ürünlerini değerlendirebilmeli, piyasayı öğrenmek için kasabadan döneceklerin yolunu gözetlemeden, telefonun kolunu çevirmeli...idi..."

\subsection{Köy Enstitüleri ve Toplumsal Kalkınma}

Köy Enstitüleri üzerinden ulusal kalkınmanın ikinci boyutunu, köyün toplumsal yönden kalkındırılması oluşturmuştur. Tek parti yönetimince köyün ekonomik kalkınmasının toplumsal kalkınma ile bütünleştiği takdirde ileri ve medeni köy haline gelebileceği düşünülmüştür. Toplumsal kalkınma kavramı zihniyette, alışkanlıklarda ve davranışlarda "medenileşme"yi yani kültürel bir dönüşümü içermektedir.

Kültür, "tarihsel toplumsal gelişme süreci içinde yaratılan bütün maddi ve manevi değerler ile bunları yaratmada, sonraki nesillere iletmede kullanılan, insanın doğal ve toplumsal çevresine egemenliğinin ölçüsünü gösteren araçların bütünü”, olarak tanımlanmaktadır (www.tdk.gov.tr). Durağan olmayıp sürekli değişkenlik ve kendi içinde; doğal akışında bir evrim içeren kültür kavramı, birey-toplum etkileşimi içinde bireylerin gündelik 
hayatlarındaki alışkanlıklarının da bir ifadesidir. Kültür kavramı bu bakımdan, "törenleri, gelenekleri, görenekleri, öyküleri, mitleri ve kahramanlıkları içerir" (Ekşioğlu, 2012:6).

Tek parti yönetiminin köy enstitüleri aracılığıyla gerçekleştirmek istediği kalkınmanın toplumsal boyutu, mevcut haliyle köy kültürünün yadsınmasını içerir. Burada söz konusu olan mevcut kültürün yerine konulmak istenen ve çağdaş/medeni olanı ifade etmesi ölçüsünde yeni olan kültürdür. Yeni kültür, "müsbet ilimden kök alan düşünüs duyuş, rasyonel çalışma, sağllk ve konfor içinde yaşama, milli şuura erme, cemiyet içinde eşit haklar sistemine göre hak ve vazife anlayışında bulunma"ya dayanan "yeni cemiyete doğru (bir) şekillenme" yi (Ağanoğlu, 1949:16) ifade etmektedir. Cumhuriyet rejiminin ilkeleri toplumsal kalkınmanın temelini oluşturur.

19 Haziran 1942 tarih ve 4274 sayılı Köy Okulları ve Enstitüleri Teşkilat Kanunu'nda köy öğretmeninin görevlerinden birisinin de köy halkının milli kültürünü yükseltmek, onları sosyal hayat bakımından çağın şartlarına göre yetiştirmek olduğu görülür (KEÇEV, 2000:138).

"Köyün ve köylünün toplumsal, kültürel, ekonomik yapısının değişmesi gerektiğini; bu değişmede kendisinin etkili ve görevli olacağını, olması gerektiğini” (Semerci, 1997:27) bilmesi gereken öğretmen, köyü ekonomik yönden canlandırmak için köye yeni teknikleri götürmekle görevli olduğu gibi, bu görevin bir tamamlayıcısı olan yeni rejimin değerlerini içeren yeni kültürü de, toplumsal kalkınma bağlamında köye götürmekle görevlendirilmiştir.

Köy Enstitülerinin kurulduğu 1940'lar Türkiyesinde nüfusun \%80 inden fazlasının köylerde yaşadığı göz önünde bulundurulunca Cumhuriyet'in köylerde yerleşmesi, bir bakıma Cumhuriyet'in yeni değerlerinin, toplumda benimsetilmesi demektir. Dolayısıyla, tek parti yönetiminin aldıkları eğitim gereği Cumhuriyet rejiminin yeni değerleriyle donatılmış bir biçimde, köylerine geri gönderilecek olan köy öğretmenleri aracılığıyla, köylerde/ülkede rejimin değerlerini yayarak bir toplumsal kalkınmayı hedeflediği söylenebilir.

İmparatorluk bakiyesi üzerinden kurulan yeni cumhuriyet rejimi, kurucu bir iktidar olarak modernleşme perspektifinden kendi değer ve ilkeleri çerçevesinde devleti ve toplumu yeniden şekillendirmek istemiştir. Oysa köy enstitülerinin kurulduğu dönem itibariyle köylüler "henüz... Cumhuriyeti yaşatacak cumhuriyet yurttaşl niteliğine kavuşmamıştır" (Aysal, 2005:270). Bu amaçla "geniş halk kitlelerinin eğitim düzeyini yükseltmek, böylece cumhuriyet reformlarının yerleşmesi için gerekli koşuları yaratmak, halkın politik, ekonomik ve kültürel yaşama aktif olarak katılmasını sağlamak yapılması gereken yönelimlerden biri" olarak kabul edilmiştir (Kartal, 2008:26).

Tek parti yönetimi cumhuriyet rejiminin ilkeleri ile toplumun ekonomik, sosyal, kültürel hayatının bütününe nüfuz ederek; çağdaş medeniyetler seviyesinin ifadesi olan “Batı tipi bir toplum yaratmaya yönelmiş”tir (Kongar, 1985:119). Tarihsel anlamda eski ile olan bağların kopması, bu çağdaş medeniyetler seviyesinin, modernleşmenin, toplumsal kalkınmanın göstergesi olarak kabul edilmiş ve bu durum dönem içerisinde "aydınlanma" olarak yorumlanmıştır. Köy enstitüleri ile gerçekleştirilecek toplumsal kalkınma sayesinde, köyün ve de köylünün "ortaçağ karanlığından kurtarılarak" (Altuntaş, 1995:2), “aydınlanmış köylü çocukları aracılığıyla" aydınlatılmasından (Velidedeoğlu, 1988:2) sıklıkla bahsedilmiştir.

Tek parti yönetiminin dönem itibariyle sahip olduğu teknik/maddi imkansızlıklar nedeniyle, "kırk bin köyün her birine bir nefes inkılap götür(erek)" (Öz, 2000:85) ülke çapında bu ilkeleri yaymak için, köy enstitüleri en temel araç olarak ortaya çıkmıştır. Tonguç'un (1948:1474) ifadesiyle, "bilgisizliği alın yazısı gibi kabul ederek, gelenek ve göreneğe uyarak yaşayan, medeniyetin nimetlerinden tamamen mahrum", köylüleri kültürel kalkınma ile medeniyete kavuşsturacak olan köy enstitüleridir. Köy enstitülerinin kuruluş gayelerinden birisi de, "Türk köylüsünü, Cumhuriyet yönetiminin icaplarına göre yetiştir(mek)" (Ağanoğlu, 1949:22) suretiyle toplumsal kalkınmayı sağlamaktır.

Köy Enstitüleri denilince, enstitülerle ilgili çalışmalarından dolayı akla gelmesi gereken ilk isim olan dönemin Milli Eğitim Bakanı Hasan Ali Yücel de Cumhuriyet Türkiyesi pratiğinde toplumsal kalkınma-cumhuriyetçilik ilişkisinde, cumhuriyetçi vatandaşlar yaratma beklentisini sık sık dile getirmekteydi. Yücel, köy enstitüsü mezunu öğretmenin, "Cumhuriyetin ve inkılâbın yayıcısı, bekçisi ve öğreticisi”", "Cumhuriyetin ve inkılâbın adamı" olduğunu, "Cumhuriyetle beraber onun ana prensipleri olarak ortaya çıkan yeni klymetlerin bu çocuklar vasıtaslyla köylere kadar yayılacağını" (Yücel, 1997:132,148,303) ifade etmiiştir.

Köye giden öğretmenler, "inkılâbı sadece sözle değil, gerçek bir kalkınma ile kökleştireceklerdi" (Akar, 1996:215). Köy Enstitülerine ilişkin çabalarından ötürü Hasan Ali Yücel ile birlikte ismi anılması gereken dönemin İlköğretim Genel Müdürü İsmail Hakkı Tonguç’un (1940:2) ifadesiyle, "bu müesseselerden çıkacak elemanlar sayesinde cümhuriyet köylere kök salacaktı". 
Tek parti yönetiminin gözünden cumhuriyetin değerlerinin köylere ulaşarak inkılâpların köye gitmesi demek, beraber köylülerin çok uzun zamandır dalmış oldukları gaflet uykusundan uyanmaları yani kültürel yönden kalkınmaları ve sonuç olarak Batı medeniyetinin nimetlerine kavuşması demekti ve köy enstitüleri "Türk köylüsünü Batı medeniyetinin nimetlerine kavuşturmak hedefi güden bir zihniyetin yarattığl kurumlar" $\mathrm{d} 1$ (Tonguç, 1948:1475).

Sonuç olarak "Köy enstitüleri sistemi başlı başına ne bir okuma-yazma kampanyası, ne bir köy kalkınması sorunu, ne bir öğretmen yetiştirme çabası, ne de bir okul yapımı girişimi idi. Temel amacı bakımından, ...devrimsel süreci hızlandırmak için girişilmiş bir devrim stratejisi ve taktiği" (Tonguç, 1970:270) yani "devrimin taban dokusu" (Velidedeoğlu, 1990:2) idi. Modernleşme doğrultusunda, cumhuriyetin değerleriyle donatılmış yeni kültüre uygun "yeni insan"1 (Türkoğlu, 1997:159) yaratmak, "yeni insanı yetişstirme(k)" (Makal, 1997:6) ulusal kalkınmanın toplumsal boyutundan beklenen asıl sonuçtu.

\section{SONUÇ}

Tek parti döneminde 1940 yılında kurulan, ancak fiiliyatta kökleri 1930'lu yıllara kadar uzanan köy enstitülerini dönemin Cumhurbaşkanı İsmet İnönü, "Cumhuriyetin eserleri içinde en klymetlisi ve en sevgilisi" (Kut, 2000:33) olarak değerlendirmiştir. Bu kıymet ve sevginin ifade edilmesinin sebebi, bu çalışmaya göre; tek parti yönetimi açısından bir okullaşma ivmesinin çok ötesinde bir anlam taşıyan köy enstitülerinin asıl kuruluş gayesi ve ondan beklenenin, enstitüler aracılığıyla ulusal kalkınmayı gerçekleştirme hedefinden kaynaklanmaktadır.

Burada kalkınmanın "ulusal” olarak değerlendirilmesi hem köy kalkınmasının, köylünün toplam ülke nüfusu içerisindeki yoğunluğundan hem de söz konusu kalkınmanın ekonomik ve toplumsal boyutu ile birlikte bütünsel bir yap1 arz etmesinden kaynaklanmaktadır. Enstitülerde "ekonomik ve toplumsal kalkınma birlikte hedeflenmiş"tir (Aysal, 2005:281).

Köy Enstitülerinde, "yaşama dair bütün konular bir bütünlük içinde" (Ortaş, 2006:3) işlenmiştir. Böylelikle enstitülü ögrretmenden, bir bütün olarak köyün ekonomik ve toplumsal kalkınmasında öncü rolü üstlenmesi beklenmiştir. Enstitüde yetişecek öğretmenin kendisinden fikir sorulabilecek, reyi alınabilecek biri olmas1 (Yücel, 1997:95), onun bir "öğretmen lider" (Sürekli, 2001:49) olarak köye "köyün dertlerini içinde duyan köyde köylü ile müştereken kazanacă̆ı zafere güven ve inanç taşıyan mütevazi ve fakat kendine güvenen kudretli bir önder olarak" (Dağlar, 1987:25) girmesi düşünülmüştür. Buradan hareketle, köy enstitülerinin, "yalnız okuyup yazma ögreten ve müfredat organlarındaki dersleri okutan pasif bir insan değil, Cumhuriyetin ve inkılâbın adamı olarak köyde önder olma vasfinda" (Yücel, 1997:303) öğretmenler yetiştirmek suretiyle, köyü içinden kalkındırarak, nihayetinde makro düzeyde ulusal kalkınmayı sağlamak amacıyla kurulmuş oldukları söylenebilir. Bu yönüyle köy enstitüleri, "bugünkü öğretmen yetiştirme kurumlarından farklı olarak toplumu değiştirme ve dönüşü̈rme, ekonomik kalkınmayı sağlama gibi önemli roller üstlenmiş" (Aykaç vd., 2018:194), "köy araştırmalarıla, örnek uygulamalarıyla çevrenin ekonomik, toplumsal, kültürel yaşamını etkileyen, ekonomik girişimlere önderlik eden kalkınma merkezleri durumuna girmişlerdir" (Bilir, 2003:13-14).

Kalkınma kavramı her ne kadar literatüre ilk kez II. Dünya Savaşı'ndan sonra ekonomik büyüme, gelişme ve bununla ilintili olarak üretim süreçlerinde olumlu bulunan sayısal artışların gerçekleşmesi olarak girmiştir. Ancak 1970'lerden sonra toplumsal ve kültürel dinamikleri de içerecek biçimde ekonomi dâhil bütünsel bir biçimde ele alınmıştır. Kavramın henüz sosyal bilimler disiplininde kullanılmadığı köy enstitüsünün kurulduğu yıllarda, tam da geniş anlamda kalkınma kavramı, tek parti yönetiminin köy enstitülerinden beklentilerini açıklayacak bir içeriği ifade etmiştir. Geç Osmanlı döneminden itibaren Türk aydının ülküselleştirdiği modernleşme, Batılılaşma, çağdaşlaşma, muasır medeniyetler seviyesine ulaşma kavram ve söylemleri, aslında bütünsel anlamda 1970'lerde ifadesini bulacak olan kalkınma kavramına denk düşmektedir.

Az gelişmişliği işaret eden ve az gelişmişlikten kurtulmayı hedefleyen kalkınma düşüncesi, aynı zamanda yönü Batı olan bir gelişme çizgisi anlamı da taşımaktadır. Tek parti yönetiminin modernleşme projesinin bir parçası, bir aracı olarak Köy Enstitüleri; köyden başlayarak ulusal ölçekte, ekonomik ve toplumsal yönden muasır medeniyetler seviyesine ulaşma hedefiyle, yönü Batı olan bu gelişme çizgisine doğru çevrilmiş bir hareket, ulusal kalkınma hedefinin bir aracı olarak değerlendirilebilir. 


\section{KAYNAKÇA}

3803 sayılı Köy Enstitüleri Kanunu (22.04.1940 tarih ve 4491 sayılı Resmi Gazete).

AĞANOĞLU, Halit (1949), Köy Enstitüleri Yolunda, Sait Basımevi, İstanbul.

AKAR, İlhan (1996), “Cumhuriyet Dönemi Eğitim Politikalarının Temel Özellikleri”, Yeni Türkiye Dergisi, S.2(7), ss.211-218.

ALTUNTAŞ, Turan (1995), “Yadirgadılar Bizi”, Cumhuriyet Gazetesi, 17 Nisan 1995, S.2.

AYDIN, Mehmet (1997), “Köy Enstitüleri Sisteminde Örgütlenme”, Köy Enstitüleri: Amaçlar-İlkelerUygulamalar, Köy Enstitüleri ve Çağdaş Eğitim Vakfi Yayını, Ankara, ss.28-36.

AYKAÇ, Murtaza, AYKAÇ, Necdet ve SARIKAYA, Hakan Serkan (2018), “Bir Moderenleşme Öyküsü: Köy Enstitüleri”, Türkish Studies, S.13(27), ss.183-201.

AYSAL, Necdet (2005), “Anadolu'da Aydinlanma Hareketinin Doğuşu: Köy Enstitüleri”, AÜ Türk İnkılâp Tarihi Enstitüsü Atatürk Yolu Dergisi, S.35-36, ss.267-282.

BAYRAM, Feridun (1999), Eğitmenler, Öğrenmeyi Öğretme Ustaları, Kültür Bakanlığı Yayınları, Ankara.

BİLİR, Mehmet (2003), “Köy Enstitüleri Sisteminde Toplum Kalkınması Süreci”, Muğla Üniversitesi Sosyal Bilimler Enstitüsü Dergisi, S.10, ss.1-15.

BİNBAŞIOĞLU, Cavit (1990), “Köy Enstitülerinde Öğretim Programları”, Abece, S.49, ss.5-9.

CANDOĞAN, Galip (1990), İvriz Köy Enstitüsündeki Öğrencilik Yıllarım, Sebat Ofset Yayıncılık, Konya.

ÇAKIR, Cengiz (1995), “Köy Enstitülerinin Tarım Ekonomisi Açısından Değerlendirilmesi”, Köy Enstitüleri ve Tarım, TMMOB Ziraat Mühendisleri Odası İzmir Şubesi Yayını, İzmir, ss.38-46.

ÇAKMAK, Özlem (2008), “Eğitimin Ekonomiye ve Kalkınmaya Etkisi”, D.Ü. Ziya Gökalp Eğitim Fakültesi Dergisi, S.11, ss.33-41.

DAĞLAR, Ahmet Lütfi (1987), Düziçi Köy Enstitüsü ve Sonrası Kimi Anılarım, Kadığlu Matbaası, Ankara.

EKŞİOĞLU, Şefika Zeynep (2012), "Kültürel Sermaye ve Ekonomik Kalkınma Arasındaki İlişsinin Girdi-Çıktı Analizi ve Fayda Maliyet Analizi Yöntemleri ile Türkiye İçin Değerlendirilmesi", Yayınlanmamış Doktora Tezi, İstanbul Üniversitesi Sosyal Bilimler Enstitüsü, İstanbul.

ERBAY, Recep (2013), “İktisadi Kalkınma Kuramlarına Eleştirel Yaklaşım”, Sosyal Bilimler Metinleri: Namık Kemal Üniversitesi Sosyal Bilimler Enstitüsü Dergisi, S.3, ss.1-30.

GEDIKKOĞLU, Şevket (1971), Evreleri Getirdikleri ve Yankılariyle Köy Enstitüleri,I̦ş Matbaası, Ankara.

GÜNER, İ. Safa (1963), Köy Enstitüleri Hatıraları, Büyük Kervan Matbaası, İstanbul.

IŞIK, Abdülkadir (2009), “Kültür ve Kalkınma: Vergi Kültürü Örneği”, Ege Akademik Bakış, S.9(2), ss.851865.

KARTAL, Sadık (2008), “Toplum Kalkınmasında Farklı Bir Eğitin Kurumu: Köy Enstitüleri”, Mersin Üniversitesi Eğitim Fakültesi Dergisi, S.4(1), ss.23-36.

KEÇEV (2000), Köy Enstitüleri İle İlgili Yasalar I, Köy Enstitüleri ve Çağdaş Eğitim Vakfı (KEÇEV) Yayınları, Ankara.

KIRBY, Fay (1962), Türkiye’de Köy Enstitüleri, İmece Yayınları, Ankara.

KONGAR, Emre (1985), İmparatorluktan Günümüze Türkiye’nin Toplumsal Yapısı 1, Remzi Kitabevi, İstanbul.

KÖY ENSTITÜLERİ ÖĞRETIMM PROGRAMI (1943), Köy Enstitüleri Öğretim Program1, Maarif Vekilliği Yayını, Ankara.

KUBAR, Yeşim (2016), “Az Gelişmiş ve Gelişmekte Olan Ülkelerin Kalkınma Göstergeleri ile Ekonomik Büyüme Arasındaki IIlişki: Bir Panel Veri Analizi”, Ardahan Üniversitesi İïBF Dergisi, S.4, ss.65-99. 
KUT, Dursun (2000), 60. Yılında Basında Köy Enstitüleri (1940-2000), Güldikeni Yayınları, Ankara.

MAKAL, Mahmut (1997), Köy Enstitüleri ve Ötesi, Güldikeni Yayınları, Ankara.

ORTAŞ, İbrahim (2006), “Ülkemizin Kaçırdığı En Büyük Eğitim Projesi: Köy Enstitüleri”, Pivolka, S.4(17), ss.3-5.

ÖNER, Sakin (1979), Köy Enstiülerinden Eğitim Enstitülerine, Su Yayınları, İstanbul.

ÖZ, Mustafa (2000), Çığlık: Köy Enstitülerine Eleştirel Bir Bakış, Tohum Yayınları, İstanbul.

SAYDUR, Mehmet ve YILMAZ, Hayati Tahsin (1994), Bir Tonguç Okulu Gölköy Enstitüsü, Görkem Yayınları, İstanbul.

SEMERCİ, Bekir (1997), Köy Enstitüleri: Amaçlar - İlkeler - Uygulamalar (Yay. Haz. Mustafa Aydoğan), Köy Enstitüleri ve Çağdaş Eğitim Vakfı Yayını, Ankara, ss.18-27.

SÜREKLİ, Kemal (2001), “Tonguç'un Yakılan Bir Kitabı ve Köy Enstitüleri”, Bilim ve Ütopya, S.80, ss.40-49.

TAŞ, Umut ve YENILMEZ, Füsun (2008), “Türkiye'de Eğitimin Kalkınma Üzerindeki Rolü ve Eğitim Yatırımlarının Geri Dönüş̧Oranı", Eskişehir Osmangazi Üniversitesi Sosyal Bilimler Dergisi, S.9(1), ss.155-186.

TDK - TÜRK DİL KURUMU (2019), “Kültür”, Güncel Türkçe Sözlük, TDK Yayını, Ankara, http://www.tdk.gov.tr (Erişim Tarihi: 12.06.2021).

TOLUNAY, Ahmet ve AKYOL, Ayhan (2006), "Kalkınma ve Kırsal Kalkınma: Temel Kavramlar ve Tanımlar”, Süleyman Demirel Üniversitesi Orman Fakültesi Dergisi, S.2, ss.116-127.

TONGUÇ, Engin (1970), Devrim Açısından Köy Enstitüleri ve Tonguç, Ant Yayınları, İstanbul.

TONGUÇ, Engin (1997), Bir Eğitim Devrimcisi İsmail Hakkı Tonguç, Güldikeni Yayınları, Ankara.

TONGUÇ, İsmail Hakk1 (1940), “Köy Terbiyesi ve Köy Enstitüleri 3”, Ulus Gazetesi, 16 Ağustos 1940, S.2.

TONGUÇ, İsmail Hakkı (1948), “Köy Enstitüleri”, Aylık Ansiklopedi, S.5(51), ss.1473-1474.

TÜRKOĞLU, Pakize (1997), Tonguç ve Enstitüleri, Yapı Kredi Kültür Sanat Yayıncılık, İstanbul.

ULUS (1940), “Maarif Vekili Köy Enstitülerinin Faydasını Anlatıyor”, Ulus Gazetesi, 1 Eylül 1940, S.1.

VELİDEDEOĞLU, Hıfzı Veldet (1988), "Köy Enstitüleri 48. Yılında”, Cumhuriyet Gazetesi, 17 Nisan 1988, S.2.

VELIDEDEOĞLU, Hıfzı Veldet (1990), “Devrimin Taban Dokusu: Köy Enstitüleri”, Cumhuriyet Gazetesi, 15 Nisan 1990, S.2.

YÜCEL, Hasan Ali (1997), Hasan Ali Yücel, Köy Enstitüleri ve Köy Eğitimi İle İlgili YazlarıKonuşmaları, Köy Enstitüleri Çağdaş Eğitim Vakfı Yayınları, Ankara. 